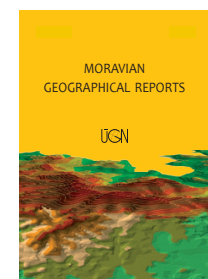

\title{
From school benches straight to retirement? Similarities and differences in the shopping behaviour of teenagers and seniors in Bratislava, Slovakia
}

\author{
František KRIŽAN $^{\text {a }}$, Kristína BILKOVÁ ${ }^{\mathrm{b}}$, Josef KUNC c ${ }^{\mathrm{c}}$, Michala SLÁDEKOVÁ MADAJOVÁ ${ }^{\mathrm{b}}$, \\ Milan ZEMAN ${ }^{\mathrm{d}}$, Pavol KITA ${ }^{\mathrm{e}}$, Peter BARLÍK ${ }^{\mathrm{f}}$
}

\begin{abstract}
The shopping behaviours of teenagers in shopping centres in Bratislava (Slovakia) is compared to those of seniors in this paper. The analysis focuses on the perception of shopping centres by teenagers and seniors in the context of time (shopping frequency), social (with whom they shop) and financial (amount of money spent) factors. The survey was conducted on random samples of 504 teenagers and 431 seniors. To test the hypotheses, group means were evaluated (Analysis of Variance models). When assessing the spatial aspects of teenagers' and seniors' shopping behaviours, a concentric zone approach was used. It can be concluded that Bratislava teenagers are not as sensitive consumers as seniors in the context of the variables assessed in the survey. Teenagers perceive shopping centres as a normal part of their consumption behaviours. Seniors perceive the shopping centres less positively and they spent a shorter time there. Also, in the case of seniors, the frequency of their visits to shopping centres increased in the context of their positive perceptions.
\end{abstract}

Keywords: shopping behaviour, teenagers, seniors, shopping centres, Bratislava, Slovakia

Article history: Received 5 December 2017, Accepted 11 September 2018, Published 30 September 2018

\section{Introduction}

The transformation of retailing in post-socialist countries engendered changes in consumer behaviours (Kunc et al., 2013; Spilková, 2012a, 2012b), in the context of demographic processes as well as changes in consumer mobility for services in the context of the shopping gradient (Maryáš et al., 2014).

With the $21^{\text {st }}$ century, new challenges have come to retail in Slovakia in terms of the continuous creation of new types of shopping equipment (shopping centres, big boxes, online sales, mail order sales and more). Original urban types of shopping centres concentrated in the city centre are confronted with outlets combining traditional shopping methods with convenience, commercial activities and operational advantages in shopping centres. These changes create a diverse set of shopping formats with distinctive functional characteristics, as well as their deployment in space. It can be noted that the new types of shopping formats that appeared on the market in terms of the rebirth and diversification of shopping, do not replace automatically existing shopping formats (Coleman, 2012). The coexistence of different shopping formats is part of the varied retail activities in an urban environment.

The popularity of shopping centres in Slovakia is constantly growing. According to the Shopping Centre Index (SCI), in 2016 shopping centres in Slovakia were visited by 63 million people (which translates to almost 60 customers per $\mathrm{m}^{2}$ of total Gross Leasable Area (GLA) per year, with the majority of visits typically occurring in December), half a million more than the year before. Compared to 2015, shopping

\footnotetext{
${ }^{a}$ Department of Regional Geography, Protection and Planning of the Landscape, Faculty of Natural Sciences, Comenius University in Bratislava, Slovakia (*corresponding author: F. Križan, e-mail: frantisek.krizan@uniba.sk)

b The Institute of Geography of the Slovak Academy of Sciences, Bratislava, Slovakia

${ }^{\mathrm{c}}$ Department of Regional Economics and Administration, Faculty of Economics and Administration, Masaryk University, Brno, Czech Republic

d The Institute for Sociology of the Slovak Academy of Sciences, Bratislava, Slovakia

${ }^{\mathrm{e}}$ Department of Marketing, Faculty of Commerce, University of Economics in Bratislava, Slovakia

${ }^{\mathrm{f}}$ Market Locator SK s.r.o., Bratislava, Slovakia
} 
visits increased more and the average sales per customer increased by $3.1 \%$. The average turnover of shopping centres also recorded an increase of 5.6\% (CBRE, 2018) in the same period. On the other hand, a counter-current that advocates alternative ways of shopping and spending leisure time has recently arisen in many post-socialist cities, including cities in Slovakia (cf. Spilková, 2016).

Shopping centre developers and retail management are constantly responding to consumer demands. On the other hand, consumers adapt their shopping and leisure time habits to new possibilities and trends. According to $\mathrm{Ng}$ (2003), shopping centres have tailored themselves to become not only centres for shopping but also community centres for social and recreational activities, leisure time, entertainment or family meetings. Consumers visit shopping centres for a variety of reasons, resulting in shopping centres taking over the role of universal service facilities. One question is how different generations (e.g. teenagers and seniors, for example) perceive shopping centres (as places for shopping and/or spending leisure time), and are there any behavioural differences also reflected in these spaces.

Shopping, as much as spending leisure time in shopping centres, does not have a long history in Slovakia. During the socialist era there were no shopping centres in their present form (Kunc et al., 2013). Now, seventeen years have passed since the opening of the first shopping centre in Bratislava. Thus, this generation of teenagers was born in the era of shopping centres while the generation of seniors lived most of their lives without them. The question is whether these two generations of consumers perceive shopping centres in Bratislava differently or not. The perception of shopping centres affects the shopping process. Positive perceptions can lead to higher spending on shopping (Shim and Eastlick, 1998), and can express satisfaction with shopping at that centre. The more satisfied shoppers are with shopping centre attributes, the more time they are likely to spend in the centre, but similar relationships do not hold for money spent in the shopping centre (Stoel et al., 2004).

The shopping behaviour of the consumer varies according to their age (Kohijoki and Marjanen, 2013; Moschis, 2003; Myers and Lumbers, 2008; Parment, 2013; Solomon et al., 2012; Zniva and Weitzl, 2016). An important aspect of retailing studies on personal characteristics and shopping involves the predictive relationship between those characteristics and shopping time (McDonald, 1994). Sommer et al. (1992) showed a positive association between age and time spent in stores. Older people spent more time in the store and bought larger amounts than younger people. This paper was also focused on the frequency of visits for shopping (Sommer et al., 1992). Different respondent age groups are significantly associated with the frequency of visits to shopping centres. Younger consumers are supposed to visit more frequently than older ones (Pattanaik et al., 2017). Another study, however, points to a positive correlation between age and visit frequency, suggesting that older people visit shopping centres more frequently (Roy, 1994). Roy (1994) also obtained an adjusted correlation between income and visit frequency, which has a low but significant value.

Different age groups of consumers spend different shares of their finances for shopping. Elderly shoppers have been found to be more price-conscious than other cohorts (Burt and Gabbott, 1995). Comparisons among consumers across the lifespan, however, do not suggest that the elderly's level of price consciousness is necessarily much greater than that of other age groups (Smith, 1988). The social context of visits to shopping centres can be considered an important aspect of shopping centre assessment. Teenagers shop most often with friends or partners, as only ten percent of them shop independently. The social function of shopping is supported by the fact that teens like being with their friends while they shop. These results clearly confirm the social role of shopping (Tootelian and Gaedeke, 1992; Kunc and Dvořák, 2016).

The aim of this paper is to evaluate the shopping behaviour of teenagers in shopping centres in Bratislava (Slovakia) in comparison with seniors. Regarding the hypothesised differential shopping behaviour of teenagers and seniors, we seek answers to the following research questions (RQ):

- RQ1: Does the share of money spent vary depending on the perception of visits to shopping centres? Is there a presumption that the positive perception of shopping centres also increases the share of money spent in shopping centres?;

- RQ2: Are there significant differences in the share of money spent in shopping centres in relation to the frequency of visits to shopping centres?;

- RQ3: Is there an interaction between the perception of shopping centres and the frequency of visits to shopping centres?; and

- RQ4: Are there significant differences in the share of money spent in shopping centres in relation to the social context of visits to shopping centres?

We have formulated the following relevant null hypotheses (H0) for these research questions:

- H01: The share of money spent in shopping centres does not depend on the perception of shopping centres; the perception of shopping centres does not affect the share of money spent in shopping centres;

- H02: The frequency of visits to shopping centres does not affect the share of money spent in shopping centres;

- H03: There is no interaction between the frequency of visits to shopping centres and the perception of shopping centres; and

- H04: Differences in the mean values between individual social context responses will be zero, and thus there will be no difference between these groups.

In relation to the different shopping behaviours of teenagers and seniors in space, the aim is to answer the following research question: RQ5 - In which of the aspects (time, social, financial, etc.) of shopping behaviour and leisure time are teenagers and seniors different?

\section{Theoretical background}

\subsection{Teenagers and their shopping preferences}

The consumers of 'generation Y' represent the children of the generation of "baby boomers" or 'generation $\mathrm{X}$ ' (Herbig et al., 1993). In this paper, teenagers are considered to be consumers aged between 14 and 19 years. Teenagers represent an interesting subject for retail researchers for at least three reasons (Arslan et al., 2010, pp. 178-179):

i. they are considered to be a strong group of shopping centre consumers;

ii. teenagers' interests in shopping centres (outside of the developed countries of Western Europe and North America) have become new public spaces; and

iii. teenagers are a specialised market segment for shopping centres. 
Visits to shopping centres by teenagers are influenced by several factors (Arslan et al., 2010): the retail environment, its comfort and its conditions, socialisation and security, availability and leisure time. As a major factor in the shopping behaviours and in spending leisure time for teenagers, technological progress and adaptation to new trends in consumer society need to be mentioned. The current generation of teenagers is the most adapted with respect to new trends (especially, compared to seniors). Specifically, for young people or teens in connection with their shopping behaviour and habits in shopping malls, according to some authors, lesser attention has been paid both to Western societies (Massicotte, 2011) and post-socialist countries in Central and Eastern Europe (Spilková and Radová, 2011). Pyyry (2016) discusses the view that in current Western societies, 'hanging around' is considered to be a deviant act because it lacks a clear goal. Such behaviours in shopping centres are more or less tolerated, however, as such young people are viewed as future customers. Harris (2005) also points out that, for young middle-class girls, strolling in shopping centres is a rare opportunity to be "off leash", without the direct supervision of an adult. Pyyry (2016) adds that this playful way of "active doing nothing" actually creates space for the existence of teenagers (being-in-theworld), because the traipsing is often pleasantly purposeless, sometimes even boring but nevertheless allows interested persons to engage and react to the surrounding conditions and environment.

The professional literature has established the concept of mall enthusiasts as 'mall junkies', which means an almost morbid addiction to the leisurely spending of free time in the shopping centre, often without their own purchases, just trying to be at the centre of events and be seen by their peers. Visiting a shopping centre without a clear goal is not only the privilege of teenagers of the advanced Western world, but also in transforming post-socialist societies (e.g. Spilková and Radová, 2011, Kunc and Dvořák, 2016).

\subsection{Seniors and their shopping preferences}

In Europe, older populations are gradually becoming dominant, and it is therefore necessary to understand them (Thompson and Thompson, 2009). In the US, consumers aged $65+$ are the richest of all age categories, with multiple sources of income (Pak and Kambil, 2006). As in other post-socialist countries of Central Europe (Káčerová et al., 2014), the population of Slovakia is also old. Over the last 100 years, the population aged $65+$ has almost tripled (Káčerová et al., 2012). The age class of seniors will grow in the future and tackling the resulting diverse socio-economic challenges will not be a matter of choice but rather a necessity. Therefore, paying attention to the older generation can be considered relevant.
Old and aging consumers are often considered a relatively homogeneous group, members of which are similar to each other but significantly different from younger age groups (Kohijoki and Marjanen, 2013). On the other hand, it can be noted that people age differently and there are differences in attitudes, wits and behaviours among people of the same age. When we consider age as a segmentation criterion, Koudelka (2005) draws attention to the dangers which are associated with age-based stereotypes that are not realitybased and which are based on the assumption that a certain age corresponds to certain shopping behaviours.

Typical and very widespread stereotypes about seniors include, for example, that all seniors are the same; they do not buy news; they are senile; they only care about themselves - and so on. It is important, however, not to be subjected to these prejudices because the numbers of people who are different is rising among seniors (e.g. rock music lovers, the 'younger' seniors who have a positive approach to technical news, etc.). Another circumstance that disturbs age stereotypes is the psychological dimension of age that is psychological age: i.e. there is a difference between real age and how old you feel. There is an even more pronounced shift between real age and age perceived, i.e. seniors mentally get young. There are also differences in spending leisure time and shopping behaviour within one generation. The question is whether these differences are manifested in the area on which this particular contribution is primarily focused (Moschis, 2012).

The shopping behaviour of seniors is influenced by several factors, the most important of which is price. Seniors are among the most price-sensitive consumers. Other important factors include the quality of the products, products intended for seniors and a caring and friendly customer service (Lesáková, 2014). Given the limited mobility of seniors, access to the place of purchase and leisure time also play an important role. The quality of the interactional aspect of service delivery is of major importance to seniors because of the emphasis they place on social interaction and strong relationships with service providers. Thus, a senior customer may repeatedly visit a service provider, not merely for commercial benefits but also for the social and emotional advantages that accrue. This highlights the importance of employees' customer-oriented interpersonal skills in the seniors' evaluations of their service encounters (Grougiou and Pettigrew, 2011).

\section{Data and methods}

\subsection{Data collection}

Data for this study were collected using a questionnaire survey in April and May of 2017. The analysis was carried out using a sample of 504 teenagers and 431 seniors (see Tab. 1).

\begin{tabular}{lcccc}
\hline \multirow{2}{*}{ Shopping Centre } & \multicolumn{2}{c}{ Teenagers } & \multicolumn{2}{c}{ Seniors } \\
\cline { 2 - 5 } & absolute & relative (\%) & absolute & relative (\%) \\
\hline Aupark & 108 & 21.5 & 97 & 22.5 \\
Avion Shopping Park & 105 & 20.8 & 85 & 19.7 \\
Bory Mall & 88 & 17.5 & 83 & 19.3 \\
Centrál & 103 & 20.4 & 93 & 21.6 \\
Eurovea & 100 & 19.8 & 73 & 16.9 \\
Total & $\mathbf{5 0 4}$ & $\mathbf{1 0 0 . 0}$ & $\mathbf{4 3 1}$ & $\mathbf{1 0 0 . 0}$ \\
\hline
\end{tabular}

Tab. 1: Number of respondents in the sampled shopping centres. Source: authors' research survey, 2017 
The questionnaire research was conducted in five shopping centres (Tab. 1). The research design was quantitative in nature, with random selection of respondents in front of or directly inside the shopping centres. Research interviews were carried out by students in the relevant master's degree programs. The questions were mainly focused on perceptions of shopping centres, and the time, social and financial aspects of shopping behaviours.

In accord with relevant official sources, the survey reveals that the majority of visitors to shopping centres in Slovakia are women (http://www.marketlocator.sk), representing more than half of the respondents. Women prevailed both in the case of seniors $(60.6 \%)$, as well as teenage respondents (56.7\%). The mean age was 68.8 years for seniors and 17.0 years for teenagers. The dominant majority of teenagers are unemployed, student consumers, often without their own income $(4.5 \%)$; on the other hand, one-tenth of seniors were employed.

\subsection{Measurement and data analysis}

To test the hypotheses, simple (one factor) Analysis of Variance (ANOVA) models for age group differences were estimated using SPSS (Gaur and Gaur, 2006). The analysed questions (dependent variables) were: Q1 - "How often do you visit shopping centres?" (with a choice of responses: Daily; Few times a week; Few times a month; Few times a year or less frequently; Never); Q2 - "How do you perceive shopping centres?" (with a choice of responses: Positive; Rather positive; Rather negative; Negative; No opinion); Q3 - "What share of your income do you spend in shopping centres per month?" (open question with an estimate in \%); and Q4 - "Who do you usually visit shopping centres with?" (with a choice of answers: Alone; With a partner; With family members/parents; With friends/acquaintances; Other; and Never visit). Since we want to determine whether the frequency of visits to shopping centres and the perception of shopping centres (Q1 and Q2) affect the share of money spent in shopping centres (Q3 - quantitative variable), while assuming the relationship between the perception and the frequency of visits (ordinal variables), we have looked for answers to questions Q1, Q2, and Q3 by using the ANOVA model for two factors with an interaction term.

\subsection{Visualisation}

Geographical Information Systems (GIS) are an important part of geographic research, including retail and consumption research (Birkin et al., 2017). GIS was used to find answers to our fifth research question (RQ5). The methodological approach applied in this part of the work can be characterised in three steps: geocoding; concentric zone formation; and analysis of shopping behaviour in concentric zones.

\subsection{Study area}

The case study region was the city of Bratislava, which is the capital of Slovakia with the largest concentration of shopping centres (15). The first shopping centre in Slovakia was opened in Bratislava in 2001. It can be said that the trend in shopping and spending leisure time in shopping centres is determined by the capital city (Križan and Lauko, 2014).

In Bratislava, we focused on the definition of concentric zones with a radius of 500 metres. The consumer shopping behaviour database from Bratislava was organised by concentric zones as this represents a way to capture the spatial differentiation of changes in shopping behaviour and respective changes in the spatial structure of the city (see Šveda, 2011). We consider this segmentation with respect to the residence of respondents to be correct because the analysis would not make sense for smaller zones, considering the number of respondents, and larger zones would not capture certain specificities in space. Terminologically, it concerns people living in areas at some distance from shopping centres. We can assume that shopping behaviours change with increasing distance from the shopping centre. The $500 \mathrm{~m}$ range in the construction of the zones has proved to be the most suitable as it does not distort the area by a number of narrow or wide zones, while taking into account the character of the analysed phenomena at an intra-urban level. As the spatial distribution of the analysed sample of consumers is heterogeneous, we have merged concentric zones beyond $2,500 \mathrm{~m}$ from the analysed shopping centres. Beyond this border, it would not be possible to discern a representative sample of respondents for individual zones. Therefore, the remaining part of the city was not divided in a more detailed way but was analysed as one concentric zone (more than 2,500 m).

Due to the size of the population, the difficulty of data collection and the variability of urban retail in Bratislava, research efforts focused on five shopping centres (Aupark, Avion Shopping Park, Bory Mall, Centrál and Eurovea). In terms of their location, these cases are typical examples of busy shopping centres in the historic centre (edge-ofcentre), out-of-centre and out-of-town (Križan et al., 2017). According to the GLA, these five are largest shopping centres in Bratislava, and according to recent research they are the most attractive (Kunc et al., 2016) and the most visited (Križan et al., 2015) centres.

\section{Results}

\subsection{Testing the hypotheses}

Table 2 shows the values for testing hypotheses on the sample of teenagers. The table demonstrates that:

\begin{tabular}{lrrrrr}
\hline Source & Sum of Squares & Df & Mean Square & \multicolumn{1}{c}{ F } & Sig. \\
\hline Model & $924,195.728^{\mathrm{a}}$ & 12 & $77,016.311$ & 157.456 & .000 \\
Q1 & $20,786.408$ & 3 & $6,928.803$ & 14.166 & .000 \\
Q2 & 454.138 & 3 & 151.379 & .309 & .819 \\
Q1 * Q2 & $3,181.912$ & 5 & 636.382 & 1.301 & .262 \\
Error & $212,282.272$ & 434 & 489.130 & & \\
Total & $\mathbf{1 , 1 3 6 , 4 7 8 . 0 0 0}$ & $\mathbf{4 4 6}$ & & & \\
\hline
\end{tabular}

Tab. 2: Hypothesis testing for teenagers: Dependent Variable Q3: "What share of your income do you spend in shopping centres per month?" (estimate in \%; $R$ Squared $=.813$ [Adjusted $R$ Squared $=.808]$ )

Source: authors' research survey, 2017 
i. while the overall model is significant $(p<0.0001)$, we cannot reject the $\mathrm{H} 01$ hypothesis at a probability level of $0.05(p=0.819)$, and therefore the perception of shopping centres does not affect the share of money spent in shopping centres (RQ1);

ii. we reject the H02 hypothesis at a level of 0.0001 , and therefore the frequency of visits to shopping centres affects the share of money spent in shopping centres (RQ2); and

iii. we cannot reject the H03 hypothesis at the level of 0.05 $(p=0.262)$, which claims that there is no interaction between the frequency of visits to shopping centres and the perception of shopping centres.

Thus, there is evidence that there is a relationship between these two factors (RQ3).

When looking for answers to RQ4 in the case of teenagers, we tested the null hypothesis (H04) that the differences in the means between the social context responses will be zero, therefore that there would be no difference between these groups. We reject this hypothesis $(\mathrm{p}=0.018)$ : the means differ for the five basic groups (Q4) (see Tab. 3). The share of money spent in the case of teenagers depends on the social context.

In the case of seniors (see Tab. 4), it was demonstrated that:

i. the overall model is highly significant ( $p<0.0001$ ), and we reject the H01 hypothesis $(\mathrm{p}=0.024)$, and therefore the perception of shopping centres affects the share of money spent in shopping centres (RQ1);

ii. we reject the H02 hypothesis ( $p=0.012$ ), and therefore the frequency of visits to shopping centres affects the share of money spent in shopping centres (RQ2); and iii. we reject the H03 hypothesis, which tested that there is no interaction between the frequency of visits to shopping centres and the perception of shopping centres, at the probability level of 0.001 .

Therefore, it was shown that there is a relationship between these two factors (RQ3).

When testing the H04 hypothesis in the case of seniors (see Tab. 5), it can be concluded that differences in the means of the social context responses $(\mathrm{Q} 4)$ is not different from zero $(p=0.263)$. The share of money spent in shopping centres in the case of seniors thus does not depend on social context.

Hence, between the teenagers' and seniors' shopping behaviours, some significant differences were confirmed (Tab. 6).

It should also be noted that the overall explanatory power of the model for the teenager sample $(\mathrm{R} 2=0.808)$ was considerably higher than for the seniors sample $(\mathrm{R} 2=0.138)$, although they are both highly significant in a statistical sense, as indicated above.

\subsection{Positive vs. negative perceptions of consumers of shopping centres}

As a relatively new phenomenon in Slovak retail trade, shopping centres are perceived not only positively but also negatively. Both teenagers and seniors have a generally positive perception of shopping centres. A more pronounced proportion of positive and rather positive (83.9\%) views were recorded for the teenagers. The seniors are more critical, and shopping centres are rated negative and even rather negative (19\%). From a spatial point of view, there is partially apparent a more positive perception of shopping

\begin{tabular}{lrrccc}
\hline Source & Sum of Squares & Df & Mean Square & F & Sig. \\
\hline Between Groups & $7,332.217$ & 4 & $1,833.054$ & 3.023 & .018 \\
Within Groups & $281,943.111$ & 465 & 606.329 & & \\
Total & $\mathbf{2 8 9 , 2 7 5 . 3 2 8}$ & $\mathbf{4 6 9}$ & & & \\
\hline
\end{tabular}

Tab. 3: Hypothesis testing for teenagers (Q3* Q4)

Source: authors' research survey, 2017

\begin{tabular}{lrrccc}
\hline Source & Sum of Squares & Df & Mean Square & F & Sig. \\
\hline Model & $3,856,297.025^{\mathrm{a}}$ & 15 & $257,086.468$ & 4.858 & .000 \\
Q1 & $590,048.202$ & 3 & $196,682.734$ & 3.716 & .012 \\
Q2 & $504,927.518$ & 3 & $168,309.173$ & 3.180 & .024 \\
Q1 * Q2 & $1,433,138.298$ & 8 & $179,142.287$ & 3.385 & .001 \\
Error & $18,258,489.975$ & 345 & $52,923.159$ & & \\
Total & $\mathbf{2 2 , 1 1 4 , 7 8 7 . 0 0 0}$ & $\mathbf{3 6 0}$ & & & \\
\hline
\end{tabular}

Tab. 4: Hypothesis testing for seniors: Dependent Variable Q3: "What share of your income do you spend in shopping centres per month?" (estimate in \%; ${ }^{a} R$ Squared $=.174$ [Adjusted $R$ Squared $=.138$ ])

Source: authors' research survey, 2017

\begin{tabular}{lrrccc}
\hline Source & Sum of Squares & Df & Mean Square & F & Sig. \\
\hline Between Groups & $319,973.461$ & 4 & $79,993.365$ & 1.316 & .263 \\
Within Groups & $25,781,350.684$ & 424 & $60,805.072$ & & \\
Total & $\mathbf{2 6 , 1 0 1 , 3 2 4 . 1 4 5}$ & $\mathbf{4 2 8}$ & & & \\
\hline
\end{tabular}

Tab. 5: Hypothesis testing for seniors $(Q 3 * Q 4)$

Source: authors' research survey, 2017 
centres by teenagers living near to them (up to $1.0 \mathrm{~km}$ ), with minimal values of negative perceptions (see Fig. 1). It is also necessary to draw attention to the fact that up to $10 \%$ of seniors do not have definite perceptions, they are neutral (in the case of teenagers this percentage is about one half).

\subsection{The time aspect of visiting shopping centres}

One of the tasks of researching shopping behaviour and spending leisure time at shopping centres is to assess the frequency of visits to shopping centres, which is influenced by a number of factors. Generally speaking, teenagers visit shopping centres for joy and amusement (leisure time) more often than seniors (see Fig. 2). Shopping for teenagers is exciting, interesting, and fun (Taylor and Cosenza, 2002), while the purchases of seniors are characterised rather as purposeful and rational (Grougiou and Pettigrew, 2011). This is why more than $45 \%$ of teenagers visit a shopping

\begin{tabular}{ccl}
\hline Hypothesis & Teenagers & Seniors \\
\hline H01 & Accepted & Rejected \\
H02 & Rejected & Rejected \\
H03 & Accepted & Rejected \\
H04 & Rejected & Accepted \\
\hline
\end{tabular}

Tab. 6: Summary of hypothesis testing

Source: authors' research survey, 2017

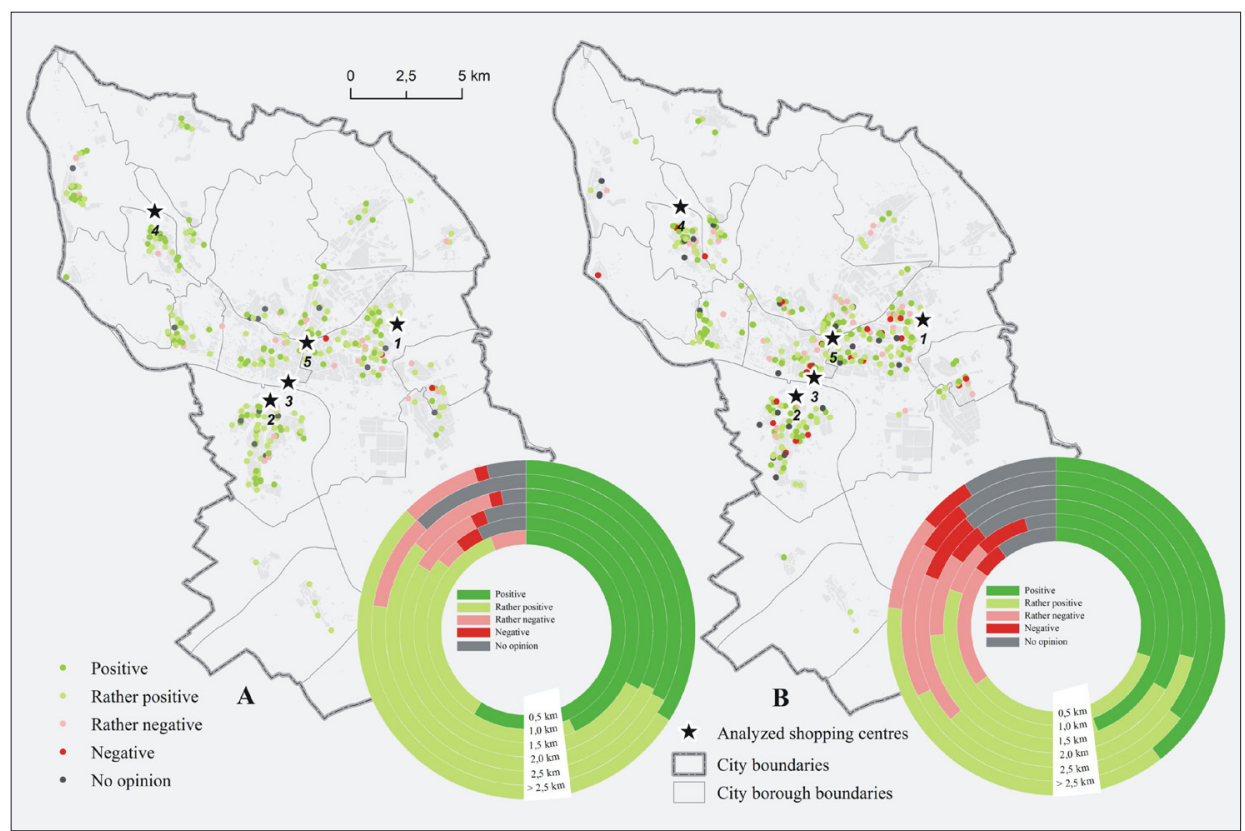

Fig. 1: Perceptions of shopping centres in Bratislava, by concentric zones (as of 2017)

Legend: A - teenagers, B - seniors; shopping centres = 1 -Avion Shopping Park; 2 - Aupark; 3 - Eurovea; 4 - Bory Mall; 5 - Centrál. Source: authors' research survey, 2017

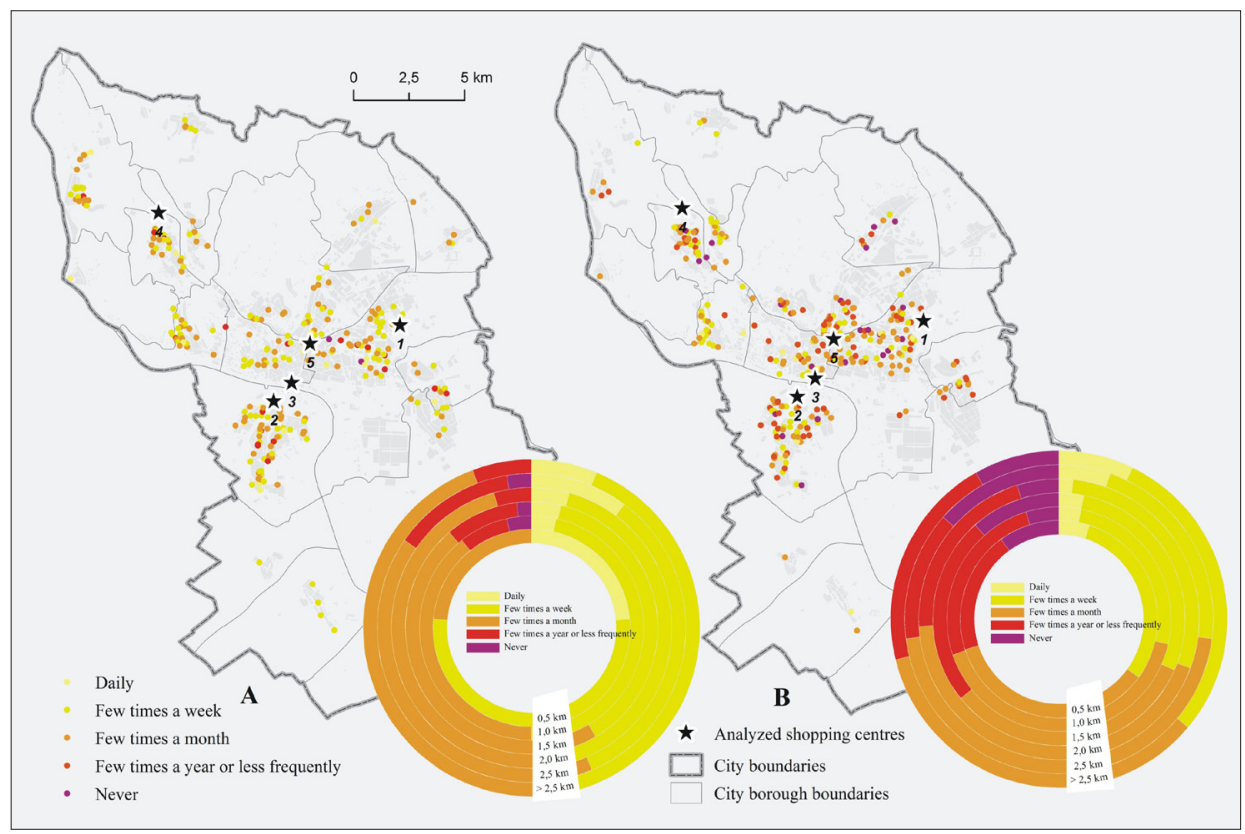

Fig. 2: Frequency of visiting shopping centres in Bratislava, by concentric zones (as of 2017)

Legend: A - teenagers, B - seniors; shopping centres = 1 - Avion Shopping Park; 2 - Aupark; 3 - Eurovea; 4 - Bory Mall; 5 - Centrál. Source: authors' research survey, 2017 
centre daily or several times a week. On the part of seniors, it is less than one third. On the other hand, almost one quarter of seniors spend leisure time in shopping centres only a few times a year or less. From a spatial point of view, it appears that the frequency of visits to shopping centres for joy and amusement (leisure time) is not dependent on the distance both for teenagers and for seniors (Fig. 2). For the teenagers, however, there is an increased frequency of visits to shopping centres in the case of a concentric zone of up to $500 \mathrm{~m}$, but this is not confirmed for seniors.

Based on the ANOVA test, the differences in time that teenagers and seniors spent in the shopping centres are statistically significant ( $\mathrm{F}=13.503 ; \mathrm{p}<0.0001)$ : teenagers spend an average of 111 minutes and seniors less than $22 \%$ of the time ( $86 \mathrm{~min}$ ) in the analysed shopping centres. For the teenagers, the smallest group spends up to 30 minutes of their time in shopping centres, but on the other hand, the smallest group of seniors spends an average time of more than 120 minutes. The group of teenagers living within $500 \mathrm{~m}$ of the shopping centre spends less time in shopping centres than teenagers living in remote locations. Conversely, for teenagers (but also seniors) living further from the shopping centre, there is a marked longer average visit time for shopping centres (see Fig. 3).

\subsection{The social aspect of visiting shopping centres}

An important element of shopping centre analysis can be the social aspect. Research suggests that group purchases lead to greater purchases and a larger spending of money (Sommer et al., 1992). The social aspect of shopping by teenagers can bring positive results for retailers (Mangleburg et al., 2004). In the case of the consumer groups analysed here, the different behaviour of teenagers and seniors have been demonstrated. The dominant social aspect for teenagers is to visit a shopping centre with friends/acquaintances $(55.2 \%)$. It should be noted that shopping with a boyfriend/ girlfriend, especially for young people, reduces the perceived risk and uncertainty that buyers associate with shopping decisions, and increases the buyer's confidence in making the right decision (Sommer et al., 1992).
On the other hand, due to age and overall social behaviour, seniors often visit the shopping centres by themselves, and shopping with friends and acquaintances was the least common response (see Tab. 7). With 95\% confidence, the average response to the question about the social context of a shopping centre visit (Q4) in the case of teenagers would be the option 'With friends/acquaintances', while for seniors it would be the options of 'Alone' and 'With a partner'.

\subsection{The financial aspect of shopping centre visits}

A final important aspect of analysing shopping behaviour in shopping centres on the one hand and spending leisure time on the other hand, can be considered the financial aspect. The task of the respondents was to estimate how much revenue they spend in shopping centres per month. The term income in this question includes all the finances available to the consumer during the month. These are finances coming from jobs, brigade-work, pocket money, pensions or other activities. The financial aspect is one indicator where the perceptions of consumers of various generations are the most different. While the average share of monthly expenses spent in shopping centres is $43.1 \%$ of income for teenagers, for seniors a level of $17.6 \%$ was reported. It should be noted that the spending of seniors in shopping centres cannot reach the level of spending of teenagers in shopping centres, as they have other expenses (rent, food, etc.) that do not show up in the outlays of teenagers. From the spatial point of view, there is no apparent dependence between the share of spending in shopping centres and the place of residence of consumers (see Fig. 4). It can be said that the average share of monthly expenses in shopping centres from income (pocket) consumers is not differentiated in this space.

\section{Discussion and conclusions}

Given the complexity of the issues and factors affecting consumer shopping behaviour and leisure time, our results cannot simply be generalised. Several general research notes can be presented, however. Firstly, it should be emphasised that this is a case study from a single city, so the results may not be reproducible for other post-socialist cities. Based on our

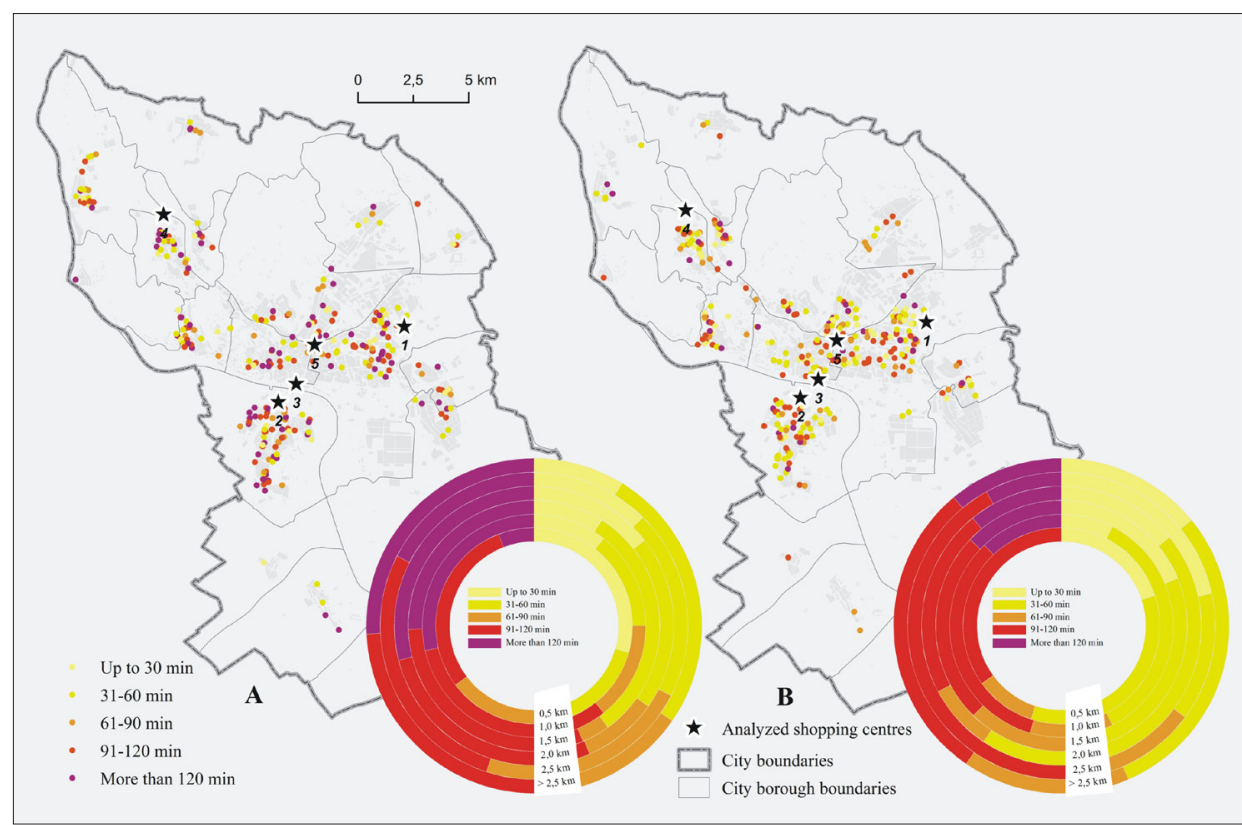

Fig. 3: Average time spent in shopping centres in Bratislava, by concentric zones (as of 2017)

Legend: A - teenagers, B - seniors; shopping centres = 1 -Avion Shopping Park; 2-Aupark; 3 - Eurovea; 4 -Bory Mall; 5 - Centrál. Source: authors’ research survey, 2017 
experience and previous research, however, we can assert that the results can be generalised to similar large cities in Central East European countries, especially those with similar economic and social development, such as in the V4 countries (the member states of the Visegrad Group, including the Czech Republic, Hungary, Poland and Slovakia).
Shopping centres are becoming the new places for spending 'free time' for teenagers who, in this study, spent most of their time in Bratislava at clothing stores, which confirms the general trends for young consumers in shopping centres (cf. Spilková and Radová, 2011). Gilboa and Yavetz (2010) stated that seniors in shopping centres stay the shortest

\begin{tabular}{|c|c|c|c|c|}
\hline Social groups ${ }^{a}$ & & Teenagers & Seniors & Total \\
\hline \multirow[t]{3}{*}{ Alone } & Count & 94 & 155 & 249 \\
\hline & Expected Count & 133 & 116 & 249 \\
\hline & $\%$ within social groups & 38 & 62 & 100 \\
\hline \multirow[t]{3}{*}{ With partner } & Count & 62 & 135 & 197 \\
\hline & Expected Count & 106 & 91 & 197 \\
\hline & $\%$ within social groups & 31 & 69 & 100 \\
\hline \multirow[t]{3}{*}{ With family / parents } & Count & 63 & 78 & 141 \\
\hline & Expected Count & 76 & 65 & 141 \\
\hline & $\%$ within social groups & 45 & 55 & 100 \\
\hline \multirow[t]{3}{*}{ With friends / acquaintances } & Count & 274 & 60 & 334 \\
\hline & Expected Count & 179 & 155 & 334 \\
\hline & $\%$ within social groups & 82 & 18 & 100 \\
\hline \multirow[t]{3}{*}{ Total } & Count & 493 & 428 & 921 \\
\hline & Expected Count & 493 & 428 & 921 \\
\hline & $\%$ within social groups & 54 & 46 & 100 \\
\hline Chi-Square Tests & Value & df & \multicolumn{2}{|c|}{ Asymptotic Sig. (2-sided) } \\
\hline Pearson Chi-Square & $176.998^{\mathrm{b}}$ & 3 & \multicolumn{2}{|c|}{.000} \\
\hline Likelihood Ratio & 188.307 & 3 & \multicolumn{2}{|c|}{.000} \\
\hline Linear-by-Linear Association & 136.781 & 1 & \multicolumn{2}{|c|}{.000} \\
\hline $\mathrm{N}$ of Valid Cases & 921 & & & \\
\hline
\end{tabular}

Tab. 7: The social aspect of visiting shopping centres

Notes: ${ }^{a}$ Excludes categories 'Other' and 'Never visits a shopping centre' (6 of 927 respondents, i.e. $0.6 \%$ ). Percentages indicated in bold are much less than expected given the marginal frequencies, percentages indicated in bold Italics are much greater than expected; ${ }^{b} 0$ cells $(0.0 \%)$ have expected count less than 5 . The minimum expected count is 65.52 .

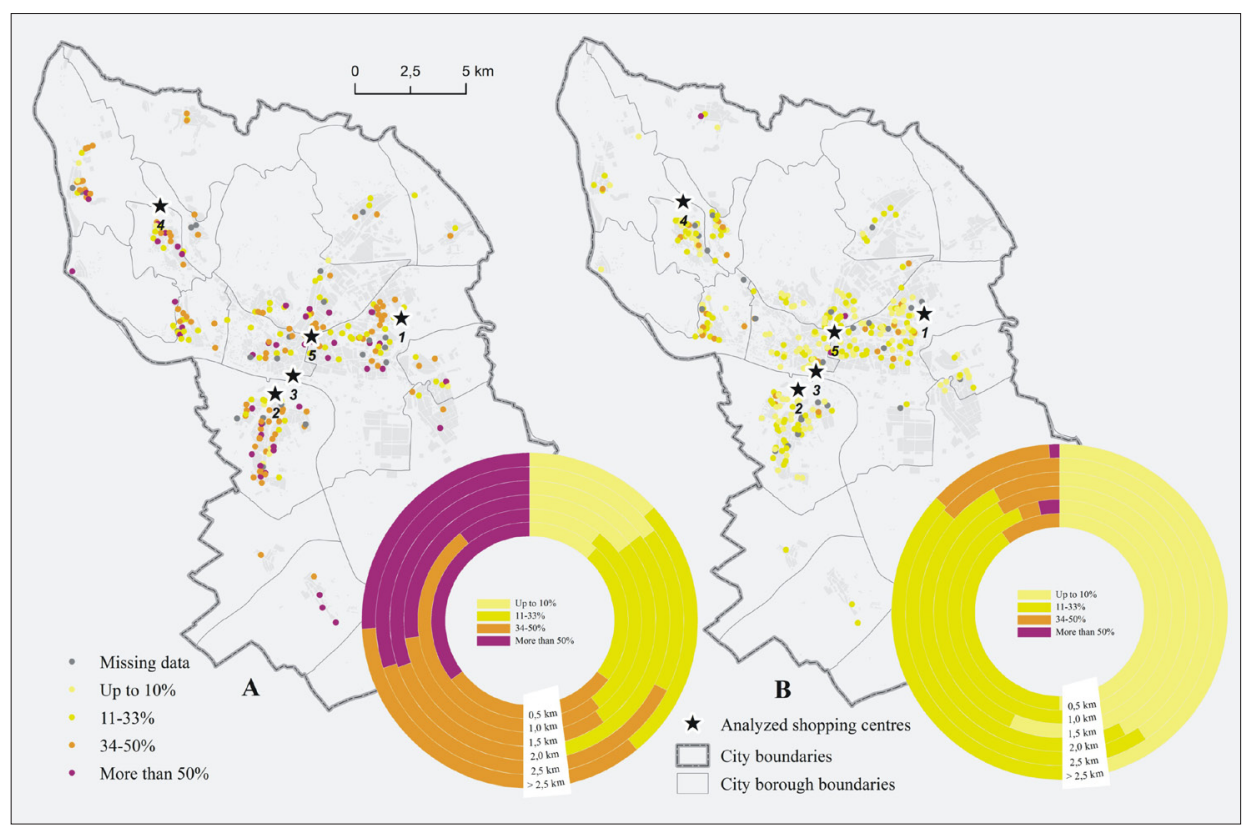

Fig. 4: Average share of monthly expenses spent in shopping centres, by concentric zones (as of 2017) Legend: A - teenagers, B - seniors; shopping centres = 1 -Avion Shopping Park; 2 - Aupark; 3 - Eurovea; 4 - Bory Mall; 5 - Centrál. Source: authors' research survey, 2017 
time, spend the least money, make fewer purchases and prefer non-branded products. Most of their trips to the mall are planned rather than spontaneous, they typically go accompanied by family members or friends, and they show a relatively high engagement in the mall's leisure activities, such as movies. As well, their comparatively high use of children's services, coupled with the fact that they often are accompanied by family, suggests that some members of this generation come to the mall to help with the grandchildren while parents go shopping.

When assessing the shopping behaviour and leisure time of seniors, it is necessary to realise that the current seniors have survived about half and even more of their lives under the socialist regime, thus in completely different socio-economic conditions. This may have some impact on their behaviour as consumers: e.g. a higher level of trust, or even credulity, which various speculators (such as street dealers, the case of the so-called schlockers, etc.) may abuse in a free market environment. Table 8 summarises the most significant findings from this analysis of shopping behaviour and leisure time in shopping centres in Bratislava.
Despite the short history of shopping centres in Bratislava (since 2001), consumers have adapted to the shopping trends in them (Križan et al., 2015). In general, positive perceptions of shopping centres can be noticed in teenagers, as well as in seniors. The positive perceptions of shopping centres in the case of teenagers do not result in an increase in the share of money spent there.

On the other hand, the perception of shopping centres and the share of money spent there were confirmed in the case of seniors (RQ1). The relationship between the frequency of visits to shopping centres and the share of money spent in them (RQ2) was confirmed in the case of Bratislava teenagers, as well as seniors. The interaction between the frequency of visits to shopping centres and the perception of shopping centres was only demonstrated in the case of seniors (RQ3). Most teenagers shop and spend leisure time at shopping centres with friends. On the contrary, seniors most often visit shopping centres on their own or with a partner. In this connection, we have analysed the share of money spent in shopping centres depending on the social context (RQ4). It has been confirmed that the share of money spent in shopping centres in the case

\begin{tabular}{ll}
\hline Generation of teenagers & Generation of seniors \\
\hline Highly positive general perception of the shopping centre & Less positive general perception of the shopping centre \\
Higher frequency of visiting the shopping centre & Lower frequency of visiting the shopping centre \\
Longer time spent in shopping centres & Shorter time spent in shopping centres \\
Remarkably strong social aspects & Seniors as individuals \\
More money spent in shopping centres & Less money spent in shopping centres \\
Higher satisfaction with the general quality of shopping centres & Low prices preferred to the general quality of shopping centres \\
Positive rating of the range of goods offered & Criticism of the range of goods offered \\
Leisure time spent in shopping centres perceived positively & Leisure time opportunities in shopping centres perceived \\
(more fun) & as inappropriate for seniors \\
\hline
\end{tabular}

Tab. 8: Comparisons of the shopping behaviour and leisure time routines of teenagers and seniors in Bratislava shopping centres in 2017. Source: Interpretations from authors' research survey, 2017

of teenagers is strongly associated with the social context. On he contrary, such dependence has not been confirmed in the case of seniors. Differences between the teenagers and seniors behaviours in shopping centres appeared in some ambiguities in space (RQ5). It is a mosaic structure that is difficult to analyse and generalise, and requires a proposal for further research using different methodological approaches. For example, in future research it is possible that a different definition of concentric zones might represent differences in space more adequately.

While shopping centres are a part of consumption for teenagers since their birth, the shopping centres are a modern retail format for seniors. It turns out that Bratislava teenagers are not as sensitive consumers as seniors in the context of the variables assessed here. Teenagers perceive shopping centres as a normal part of their consumption. Seniors spend a greater share of money in shopping centres along with a positive perception of shopping centres. Also, in the case of seniors, the frequency of visits to shopping centres is increasing in the context of their positive perceptions.

The results of this analysis can be applied in the marketing strategies of shopping centres focused on their visitors. In this case, there is no fundamental aspect of economic development. Owners of shopping centres are becoming more and more aware that consumers' reactions to a rapidly changing retail environment will depend upon their preferences and the environment in which they are made (Kita et al., 2017). As stressed by Leszczyc et al. (2000), for the retailers as well as shopping centres, the problem is how to cope with increased competition in light of the dynamics of consumer shopping behaviour (see also Maryáś et al., 2014).

With respect to spending leisure time, it seems clear that it has a different character for different generations: as Thompson and Thompson stated (2009), it is difficult to empathise with people two generations older than you, after all, a 65 -year old knows what it was like to be 30 , but a 30 year old does not know what it is like to be 65 . Therefore, a continuous assessment of the shopping behaviour of consumers of different generations can be considered a useful tool for marketing decision making.

\section{Acknowledgements}

This work was supported by the Slovak Research and Development Agency under the contracts: No. APVV-160232 and No. APVV-15-0184; and by the internal project of Masaryk University: "Cities, municipalities, regions: management, processes and interactions in theory and practice" (MUNI/A/0994/2017). 


\section{References:}

ARSLAN， T. V., SEZER， F. S., ISIGICOK， E. (2010): Magnetism of shopping malls on young Turkish consumers. Young Consumers: Insight and Ideas for Responsible Marketers, 11(3): 178-188.

BIRKIN, M., CLARKE, G., CLARKE, M. (2017): Retail location planning in an era of multi-channel growth. New York, Routledge.

BURT, S., GABBOTT, M. (1995): The elderly consumer and non-food purchase behaviour. European Journal of Marketing, 29(2): 43-57.

CBRE (2018): Czech Republic Retail MarketView H1 2018 [online]. [cit. 17.09.2018]. Available at https://www.cbre. cz/en/research-and-reports

COLEMAN, P. (2012): Shopping Environments. London, Routledge.

GAUR, A. S., GAUR, S. S. (2006): Statistical methods for practice and research: A guide to data analysis using SPSS. London, Sage.

GILBOA, S., VILNAI-YAVETZ, I. (2010): Four generations of mall visitors in Israel: A study of mall activities, visiting patterns, and products purchased. Journal of Retailing and Consumer Services, 17(6): 501-511.

GROUGIOU, V., PETTIGREW, S. (2011): Senior customers' service encounter preferences. Journal of Service Research, 14(4): 475-488.

HARRIS, D. (2005): Key concepts in leisure studies. London, Sage.

HERBIG, P., KOEHLER, W., DAY, K. (1993): Marketing to the baby bust generation. Journal of Consumer Marketing, 10(1): 4-9.

KÁČEROVÁ, M., ONDAČKOVÁ, J., MLÁDEK, J. (2012): A comparison of population ageing in the Czech Republic and the Slovak Republic based on generation support and exchange. Moravian Geographical Reports, 20(4): 26-38.

KÁČEROVÁ, M., ONDAČKOVÁ, J., MLÁDEK, J. (2014): Time-space differences of population ageing in Europe. Hungarian Geographical Bulletin, 63(2): 177-199.

KITA, P., FURKOVÁ, A., REIFF, M., KONŠTIAK, P., SITÁŠ́VÁ, J. (2017): Impact of Consumer Preferences on Food Chain Choice: An empirical study of consumers in Bratislava. Acta Universitatis Agriculturae et Silviculturae Mendelianae Brunensis, 65(1): 293-298.

KOHIJOKI, A. M., MARJANEN, H. (2013): The effect of age on shopping orientation-choice orientation types of the ageing shoppers. Journal of Retailing and Consumer Services, 20(2): 165-172.

KOUDELKA, J. (2005): Segmentujeme spotřební trhy. Praha, Professional publishing.

KRIŽAN, F., BILKOVÁ, K., KITA, P., KUNC, J., BARLÍK, P. (2015): Nákupné centrá v Bratislave a atribúty ovplyvňujúce preferencie spotrebitel'ov. Geografický časopis, 67(4): 341-357.

KRIŽAN, F., KUNC, J., BILKOVÁ, K., BARLÍK, P., ŠILHAN, Z. (2017): Development and classification of shopping centers in Czech and Slovak Republics: comparative analysis. Acta Universitatis Carolinae Geographica, 52(1): 18-26.
KRIŽAN, F., LAUKO, V. (2014): Geografia maloobchodu. Úvod do problematiky. Bratislava, Univerzita Komenského.

KUNC, J., DVOŘÁK, Z. (2016): Attractiveness of Brno Shopping Centres for Teenagers: Vaňkovka or Olympia?. In: Klímová, V., Žítek, V. [eds.]: $19^{\text {th }}$ International Colloquium on Regional Science, Conference Proceedings (pp. 556-564). Brno, Masaryk University.

KUNC, J., MARYÁŠ, J., TONEV, P., FRANTÁL, B., SIWEK, T., HALÁS, M., KLAPKA, P., SZCZYRBA, Z., ZUSKÁČOVÁ, V. (2013): Časoprostorové modely nákupního chování české populace. Brno, Masarykova univerzita.

LESÁKOVÁ, D. (2014): Tendencie spotrebitel'ského správania a spotreby $\mathrm{v}$ domácnostiach dôchodcov na Slovensku. Ekonomický časopis, 62(8): 823-841.

LESZCZYC, P. T. P., SINHA, A., TIMMERMANS, H. J. (2000): Consumer store choice dynamics: an analysis of the competitive market structure for grocery stores. Journal of Retailing, 76(3): 323-345.

MANGLEBURG, T. F., DONEY, P. M., BRISTOL, T. (2004): Shopping with friends and teens' susceptibility to peer influence. Journal of Retailing, 80(2): 101-116.

MARYÁŠ, J., KUNC, J., TONEV, P., SZCZYRBA, Z. (2014): Shopping and services related travel in the hinterland of Brno: Changes from the Socialist Period to the Present. Moravian Geographical Reports, 22(3): 18-28.

MASSICOTTE, M. C., MICHON, R., CHEBAT, J. C., SIRGY, M. J., BORGES, A. (2011): Effects of mall atmosphere on mall evaluation: Teenage versus adult shoppers. Journal of Retailing and Consumer Services, 18(1): 74-80.

MCDONALD, W. J. (1994): Time use in shopping: the role of personal characteristics. Journal of Retailing, 70(4): 345-365.

MOSCHIS, G. P. (2003): Marketing to older adults: an updated overview of present knowledge and practice. Journal of Consumer Marketing, 20(6): 516-525.

MOSCHIS, G. P. (2012): Consumer behavior in later life: Current knowledge, issues, and new directions for research. Psychology \& Marketing, 29(2): 57-75.

MYERS, H., LUMBERS, M. (2008): Understanding older shoppers: a phenomenological investigation. Journal of Consumer Marketing, 25(5): 294-301.

NG, C. F. (2003): Satisfying shoppers' psychological needs: From public market to cyber-mall. Journal of Environmental Psychology, 23(4): 439-455.

PAK, C., KAMBIL, A. (2006): Over 50 and ready to shop: serving the aging consumer. Journal of Business Strategy, 27(6): 18-28.

PARMENT, A. (2013): Generation Y vs. Baby Boomers: Shopping behavior, buyer involvement and implications for retailing. Journal of retailing and consumer services, 20(2): 189-199.

PATTANAIK, S., MISHRA, B. B., MOHARANA, T. R. (2017): How Consumer Demographics is Associated with Shopping Behaviour? A Study on Indian Consumers. Siddhant-A Journal of Decision Making, 17(2): 195-206.

PYYRY, N. (2016). Participation by being: Teenage girls' hanging out at the Shopping Mall as 'dwelling with' [the World]. Emotion, Space and Society, 18: 9-16. 
ROY, A. (1994): Correlates of mall visit frequency. Journal of Retailing, 70(2): 139-161.

SHIM, S., EASTLICK, M.A. (1998): The hierarchical influence of personal values on mall shopping attitude and behavior. Journal of Retailing, 74(1): 139-160.

SMITH, G. C. (1988): The spatial shopping behaviour of the urban elderly: a review of the literature. Geoforum, 19(2): 189-200.

SOLOMON, M., RUSSELL-BENNETT, R., PREVITE, J. (2012): Consumer Behaviour. A European Perspective. London, Pearson.

SOMMER, R., WYNES, M., BRINKLEY, G. (1992): Social facilitation effects in shopping behavior. Environment and Behavior, 24(3): 285-297.

SPILKOVÁ, J. (2012a): Geografie maloobchodu a spotřeby: věda o nakupování. Praha, Karolinum.

SPILKOVÁ, J. (2012b): The birth of the Czech mall enthusiast: the transition of shopping habits from utilitarian to leisure shopping. Geografie, 117(1): 21-32.

SPILKOVÁ, J. (2016): Alternativní potravinové sítě: Česká cesta. Prague, Karolinum Press.

SPILKOVÁ, J., RADOVÁ, L. (2011): The formation of identity in teenage mall microculture: A case study of teenagers in Czech malls. Sociologický časopis, 47(3): 565-586.
STOEL, L., WICKLIFFE, V., LEE, K. H. (2004): Attribute beliefs and spending as antecedents to shopping value. Journal of Business Research, 57(10): 1067-1073.

ŠVEDA, M. (2011): Suburbanizácia v zázemí Bratislavy z hladiska analýzy zmien krajinnej pokrývky. Geografický časopis, 63(2): 155-173.

TAYLOR, S. L., COSENZA, R. M. (2002): Profiling later aged female teens: mall shopping behavior and clothing choice. Journal of Consumer Marketing, 19(5): 393-408.

THOMPSON， N. J.， THOMPSON， K. E. (2009): Can marketing practice keep up with Europe's ageing population? European Journal of Marketing, 43(11/12): 1281-1288

TOOTELIAN, D. H., GAEDEKE, R.M. (1992): The team market: an exploratory analysis of income, spending and shopping patterns. Journal of Consumer Marketing, 9(4): 35-44.

ZNIVA, R., WEITZL, W. (2016): It's not how old you are but how you are old: A review on aging and consumer behavior. Management Review Quarterly, 66(4): 267-297.

Please cite this article as:

KRIŽAN, F., BILKOVÁ, K., KUNC, J., SLÁDEKOVÁ MADAJOVÁ, M., ZEMAN, M., KITA, P., BARLÍK, P. (2018): From school benches straight to retirement? Similarities and differences in the shopping behaviour of teenagers and seniors in Bratislava, Slovakia. Moravian Geographical Reports, 26(3): 199-209. Doi: 10.2478/mgr-2018-0016. 